\title{
Potensi ekstrak daun singkong (Manihot esculenta Crantz.) terhadap profil leukosit darah tepi model tikus disfungsi ovarium dan periodontitis
}

\author{
Lutfi Meiga Sari ${ }^{1}$, Zahara Meilawaty $^{1 *}$, Pudji Astuti ${ }^{1}$, Amandia Dewi Permana Shita ${ }^{1}$, \\ Agustin Wulan Suci Dharmayanti ${ }^{1}$, Zahreni Hamzah ${ }^{1}$
}

\author{
${ }^{1}$ Departemen Biomedik, Fakultas Kedokteran Gigi Universitas Jember, Indonesia
}

*Korespondensi: zahara.fkg@unej.ac.id

Submisi: 25 November 2020; Penerimaan: 30 April 2021; Publikasi online: 30 April 2021

DOI: $10.24198 / \mathrm{jkg} . \mathrm{v} 33 \mathrm{i} 1.30751$

\begin{abstract}
ABSTRAK
Pendahuluan: Disfungsi ovarium merupakan keadaan ovarium yang mengalami kegagalan dalam sekresi hormon seks steroid. Penurunan sekresi hormon terutama estrogen dapat memicu peningkatan sitokin proinflamasi seperti IL-1, IL-6 dan TNF- $\alpha$ yang berperan dalam resorpsi tulang dan reaksi inflamasi periodontal. Salah satu drug of choice dari periodontitis adalah metronidazole. Penggunaan metronidazole secara sistemik dapat mengakibatkan efek samping, sehingga diperlukan bahan alternatif yang memiliki efek terapi antiinflamasi. Salah satu tanaman yang memiliki efek antiinflamasi adalah daun Singkong. Tujuan penelitian adalah menganalisis potensi ekstrak daun Singkong sebagai antiinflamasi terhadap profil leukosit darah tepi model tikus disfungsi ovarium dan periodontitis. Metode: Jenis penelitian eksperimental laboratoris dengan post-test only control group design. Sampel penelitian sebanyak 18 ekor tikus betina yang dibagi menjadi dua kelompok besar yakni kelompok disfungsi ovarium dan kelompok kecil periodontitis. Pembuatan model tikus disfungsi ovarium dan tikus periodontitis dilakukan selama 28 hari. Setelah masing-masing kelompok dibagi menjadi 3 kelompok yang diberikan perlakuan aquades, metronidazole dan ekstrak daun Singkong selama 7 hari. Setiap tikus diambil darahnya melalui plexus infraorbitalis pada hari ke-1, hari ke-3 dan hari ke-7. Darah yang diambil selanjutnya dilakukan perhitungan jumlah sel leukosit darah tepi menggunakan kamar hitung dan perhitungan jenis dengan cara visual. Hasil: Hasil uji LSD menunjukkan bahwa terdapat perbedaan bermakna jumlah leukosit darah tepi antar hari pada kelompok tikus yang mengalami disfungsi ovarium $(p \leq 0,05)$. Simpulan: Ekstrak daun Singkong (Manihot esculenta Crantz) dapat menurunkan profil leukosit perifer model tikus disfungsi ovarium dan periodontitis.
\end{abstract}

Kata kunci: Disfungsi ovarium, periodontitis, profil leukosit perifer, ekstrak daun singkong.

\section{Potential of cassava leaves (Manihot esculenta Crantz.) extract on peripheral blood leukocyte profile in ovary dysfunction and periodontitis rat model}

\section{ABSTRACT}

Introduction: Ovarian dysfunction is when the ovaries fail in the secretion of steroid sex hormones. Decreased secretion of hormones, especially estrogen, can trigger an increase in pro-inflammatory cytokines such as IL-1, IL-6 and TNF- $\alpha$, which play a role in bone resorption and periodontal inflammatory reactions. One drug of choice for periodontitis is metronidazole. Systemic use of metronidazole can cause side effects, so an alternative material with a therapeutic anti-inflammatory effect is needed. One of the plants that have an anti-inflammatory effect is cassava leaves. The research objective was to analyse the potential of cassava leaf extract as an anti-inflammatory against the peripheral blood leukocyte profile in a mouse model of ovarian dysfunction and periodontitis. Methods: This was an experimental laboratory study with a post-test only control group design. The research sample consisted of 18 female rats divided into two large groups: the ovarian dysfunction group and the small periodontitis group. The making of mouse models of ovarian dysfunction and periodontitis rats was carried out for 28 days. After each group was divided into three groups treated with distilled water, metronidazole and cassava leaf extract for seven days. Blood was drawn from each mouse through the infraorbital plexus on day 1, day three, and 7. The blood that was taken was then performed to calculate the number of peripheral blood leukocytes using the counting room and the calculation of the type by visual means. Results: The results of the LSD test showed that there was a significant difference in the number of peripheral blood leukocytes between days in the group of rats with ovarian dysfunction ( $p \leq 0.05)$. Conclusion: Cassava leaf extract (Manihot esculenta Crantz) can reduce the profile of peripheral leukocytes in a mouse model of ovarian dysfunction and periodontitis.

Keywords: Ovarian dysfunction, periodontitis, peripheral leukocytes profile, cassava leaf extract. 


\section{PENDAHULUAN}

Disfungsi ovarium merupakan kegagalan fungsi ovarium dalam sekresi hormon seks steroid terutama estrogen dan progesteron. Hal ini terjadi akibat hilangnya aktivitas atau tidak berfungsinya folikelovarium sehingga menyebabkan menurunnya sekresi hormon tersebut. Penurunan konsentrasi hormon seks steroid dalam tubuh terutama estrogen dapat berdampak pada kesehatan umum terutama sebagai kelainan somatik/ urogenital dan vasomotor. $^{1}$

Adanya hubungan antara perubahan hormonal dengan penyakit periodontal ditemukan pada wanita. Menopause dapat berperan sebagai faktor resiko terjadinya penyakit periodontal. ${ }^{2}$ Perubahan estrogen, progesteron, dan hormon wanita lainnya telah dilaporkan memiliki efek pada interleukin-1 (IL-1), interleukin-6 (IL-6), dan sekresi tumor necrosis factor- $\alpha$ (TNF- $\alpha$ ) yang merupakan sitokin proinflamasi yang berperan dalam resorpsi tulang dan reaksi inflamasi periodontal. ${ }^{3}$

Porphyromonas gingivalis merupakan salah satu bakteri gram negatif yang dapat menyebabkan periodontitis. Lipopolisakarida pada P.gingivalis merupakan salah satu faktor virulensi dan dapat menginduksi inflamasi yang melibatkan sitokin pro inflamasi diantaranya IL-1 dan TNF- $\alpha$. IL-1 berperan dalam menginduksi PMN (polymorphonuclear) untuk bergerak menuju daerah infeksi, sedangkan TNF- $\alpha$ berperan dalam menghambat apoptosis dari PMN, yang mengakibatkan meningkatnya infiltrasi PMN dapat dilihat pada setiap tahap periodontitis. ${ }^{4}$

Metronidazole merupakan salah satu drug of choice untuk penyakit periodontal. Metronidazole efektif terhadap bakteri anaerob seperti P.gingivalis. Pemberian metronidazole dapat dilakukan secara sistemik, namun terdapat efek samping seperti mual, mulut kering, gangguan pencernaan dan berasa logam di mulut. ${ }^{5}$ Adanya efek samping yang telah disebutkan, maka penelitian menggunakan bahan alam diharapkan dapat menjadi solusi untuk meminimalkan efek samping tersebut.

Salah satu bahan alam yang mempunyai efek terapi yakni daun Singkong (Manihot esculenta). Kandungan yang terdapat dalam daun Singkong yaitu air, fosfor, karbohidrat, kalsium, vitamin C, protein, lemak, vitamin B1, zat besi, flavonoid, saponin, tanin dan triterpenoid. ${ }^{6}$ Penelitian terdahulu menyebutkan bahwa daun Singkong dapat berpotensi sebagai antiinflamasi. Daun Singkong memiliki efek antiinflamasi yang mirip dengan obat kimia aspirin. Efek ini diduga karena adanya kandungan flavonoid dan saponin yang terdapat pada daun Singkong dapat menghambat siklus siklooksigenase. ${ }^{7}$ Tujuan penelitian adalah menganalisis potensi ekstrak daun Singkong sebagai antiinflamasi terhadap profil leukosit darah tepi model tikus disfungsi ovarium dan periodontitis.

\section{METODE}

Jenis penelitian eksperimental laboratoris dengan rancangan the posttest only control group. Populasi penelitian yang digunakan adalah 18 ekor tikus putih betina dari galur Sprague Dawley (Rattus norvegicus), umur 2-3 bulan, berat badan \pm 200 gram, tikus dalam keadaan sehat ditandai dengan respon gerakan aktifnya, tidak cacat, dan belum pernah digunakan untuk penelitian sebelumnya.

Identifikasi tanaman singkong dilakukan di Lembaga IImu Pengetahuan Indonesia (LIPI) melalui Balai Konservasi Tumbuhan (BKT) Kebun Raya Purwodadi, Malang, Jawa Timur. Pembuatan ekstrak dilakukan di Laboratorium Analisis Terpadu Fakultas Teknologi Pertanian Universitas Jember. Daun Singkong yang digunakan berasal dari daerah Kreongan, Kabupaten Jember. Daun Singkong yang dipetik kemudian dicuci bersih, dipotong kecil-kecil dan didinginkan pada suhu ruang dan tidak terkena cahaya matahari langsung. Daun Singkong dikeringkan di oven pada suhu $40^{\circ} \mathrm{C}$ selama 24 jam penuh kemudian dihaluskan dan diayak menggunakan ayakan 80 maze. Serbuk halus daun Singkong dimaserasi dengan etanol $96 \%$ dengan rasio simplisia : pelarut sebesar $1: 6$ (250 gram: 1.5 liter) selama 3 hari dan dilakukan pengadukan setiap 24 jam. Larutan dipekatkan dengan rotary evaporator dengan suhu $50^{\circ} \mathrm{C}$ dan putaran $90 \mathrm{rpm}$ sehingga menjadi ekstrak daun Singkong (Manihot esculenta Crantz) $100 \%$ berbentuk semi solid.Prosedur maserasi ini berdasarkan modifikasi dari Meilawaty. ${ }^{8}$

Hewan coba dibagi secara acak menjadi 2 kelompok yaitu (1) kelompok tikus disfungsi ovarium dan (2) kelompok tikus periodontitis. Masing-masing kelompok dibagi lagi menjadi 3 sub kelompok yaitu Kelompok kontrol negatif yang diberi aquades (K-), Kelompok kontrol positif yang diberi metronidazole $(\mathrm{K}+)$, dan kelompok perlakuan 
yang diberi ekstrak daun Singkong $(P)$. Setiap sub kelompok terdiri dari 3 tikus betina. Pembuatan model tikus disfungsi ovarium dilakukan dengan cara menggunakan prosedur ovariektomi. Pada hewan coba dilakukan dengan insisi transversal dengan ukuran 0,5-1 cm menggunakan scalpel blade nomor 11 dan ditunggu sampai 28 hari. $^{9}$ Pembuatan model tikus periodontitis dilakukan dengan cara injeksi bakteri $P$. gingivalis pada sulkus gingiva $0,05 \mathrm{ml}$ di bukal dan lingual molar bawah kiri, diberikan tiga hari sekali selama 28 hari menggunakan tuberculine syringe dengan ukuran jarum 30 gauge. ${ }^{10}$

Dosis metronidazole yang digunakan sebagai kontrol positif adalah 0,045 mg/gr BB. Hal ini sesuai dengan konversi dosis metronidazole pada manusia yaitu $500 \mathrm{mg}$ per hari. Berdasarkan penelitian terdahulu, dosis ekstrak daun singkong yang digunakan adalah 179,2 mg/kg BB tikus. Pemberian aquades, metronidazole dan ekstrak daun singkong dilakukan selama 7 hari. $^{7}$

Pengambilan darah tepi dilakukan sebelum tikus diberi perlakuan, pada hari ke-28, hari ke31 dan hari ke-35. Pengambilan sampel darah dilakukan pada plexus infraorbital sekitar 1,5-2 cc. ${ }^{9}$ Pengamatan profil leukosit meliputi perhitungan jumlah dan jenis leukosit. Perhitungan jumlah leukosit menggunakan kamar hitung. Perhitungan jenis leukosit dilakukan secara visual pada hapusan darah yang telah diwarnai menggunakan giemsa. Pengamatan dilakukan menggunakan mikroskop Olympus cx21 dengan perbesaran 1000x. Analisis data dilakukan dengan uji Two-way repeated measures ANOVA yang dilanjutkan dengan uji LSD. Ethical clearance prosedur perlakuan pada penelitian ini disetujui oleh Unit Etika dan Advokasi, Fakultas Kedokteran Gigi, Universitas Gadjah Mada dengan nomor 00358/KKEP/FKG-UGM/ EC/2020.

\section{HASIL}

Perhitungan jumlah dan jenis pada penelitian ini telah dilakukan pada bulan Februari 2020 di Laboratorium Patologi Klinik Fakultas Kedokteran Universitas Jember. Tujuan dari penelitian ini adalah untuk mengetahui potensi ekstrak daun Singkong (Manihot esculenta Crantz) terhadap profil leukosit darah tepi tikus disfungsi ovarium dan periodontitis. Rata-rata hitung jumlah dan jenis leukosit pada model tikus disfungsi ovarium dan periodontitis ditunjukkan pada Tabel 1 dan Tabel 2 .

Tabel 1. Perhitungan rata-rata jumlah dan jenis leukosit model tikus disfungsi ovarium

\begin{tabular}{|c|c|c|c|c|c|}
\hline & & $\begin{array}{c}\text { Normal } \\
X \pm S D\end{array}$ & $\begin{array}{c}\text { Hari Ke-1 } \\
\pm \mathrm{SD}\end{array}$ & $\begin{array}{c}\text { Hari Ke-3 } \\
\quad \pm \text { SD }\end{array}$ & $\begin{array}{c}\text { Hari Ke-7 } \\
\pm \mathrm{SD}\end{array}$ \\
\hline \multirow{3}{*}{$\begin{array}{l}\text { Rata-rata jumlah leukosit } \\
\left(\mathrm{sel} / \mathrm{mm}^{3}\right)\end{array}$} & K- & $7050 \pm 608,3$ & $6516,7 \pm 852$ & $5466,7 \pm 450,9$ & $10500 \pm 700$ \\
\hline & $\mathrm{K}+$ & $7950 \pm 800$ & $5666,7 \pm 850,5$ & $5233,3 \pm 539,3$ & $8783,33 \pm 189,3$ \\
\hline & $\mathrm{P}$ & $7216,7 \pm 275,4$ & $6266,7 \pm 1375,1$ & $9000 \pm 1789,6$ & $7983,33 \pm 1069,3$ \\
\hline \multirow{3}{*}{ Rata-rata basofil (\%) } & $\mathrm{K}-$ & $0,7 \pm 0,6$ & - & - & - \\
\hline & $\mathrm{K}+$ & $0,7 \pm 0,6$ & - & - & - \\
\hline & $\mathrm{P}$ & - & - & - & - \\
\hline \multirow{3}{*}{ Rata-rata eusinofil (\%) } & K- & $2,3 \pm 0,6$ & 2 & - & $1,67 \pm 0,6$ \\
\hline & $\mathrm{K}+$ & $2,7 \pm 0,6$ & 2 & - & $1 \pm 1,7$ \\
\hline & $\mathrm{P}$ & $1,3 \pm 0,6$ & $1,67 \pm 1,2$ & 1 & $1 \pm 1$ \\
\hline \multirow{3}{*}{ Rata-rata neutrofil (\%) } & $\mathrm{K}-$ & $61,3 \pm 1,2$ & $50,3 \pm 7,1$ & $40,7 \pm 3,1$ & $37,7 \pm 9$ \\
\hline & $\mathrm{K}+$ & $60,7 \pm 2$ & $43,7 \pm 1,6$ & $26,7 \pm 3$ & $30,3 \pm 0,6$ \\
\hline & $\mathrm{P}$ & $55,3 \pm 3,5$ & $38,3 \pm 2,1$ & $37 \pm 3,5$ & $53,3 \pm 3,5$ \\
\hline \multirow{3}{*}{ Rata-rata limfosit (\%) } & $\mathrm{K}-$ & $32,7 \pm 1,2$ & $46,7 \pm 2,9$ & $56,7 \pm 3,1$ & $57,3 \pm 6,1$ \\
\hline & $\mathrm{K}+$ & $32 \pm 1$ & $50 \pm 1$ & $71,7 \pm 4,9$ & $64,3 \pm 0,6$ \\
\hline & $\mathrm{P}$ & $38,3 \pm 3,5$ & $56,3 \pm 1,5$ & $60 \pm 3$ & $42,7 \pm 4,6$ \\
\hline \multirow{3}{*}{ Rata-rata monosit (\%) } & $\mathrm{K}-$ & 3 & $4,3 \pm 0,6$ & $2,7 \pm 1,2$ & $3,3 \pm 2,9$ \\
\hline & $\mathrm{K}+$ & $4 \pm 2$ & $4 \pm 1$ & $1,7 \pm 2,1$ & $1 \pm 1$ \\
\hline & $P$ & $5 \pm 1$ & $3,7 \pm 1,5$ & $2 \pm 1,7$ & $3 \pm 2$ \\
\hline
\end{tabular}

Keterangan: K- : Aquades, K+ : Metronidazole, P : Ekstrak daun singkong 


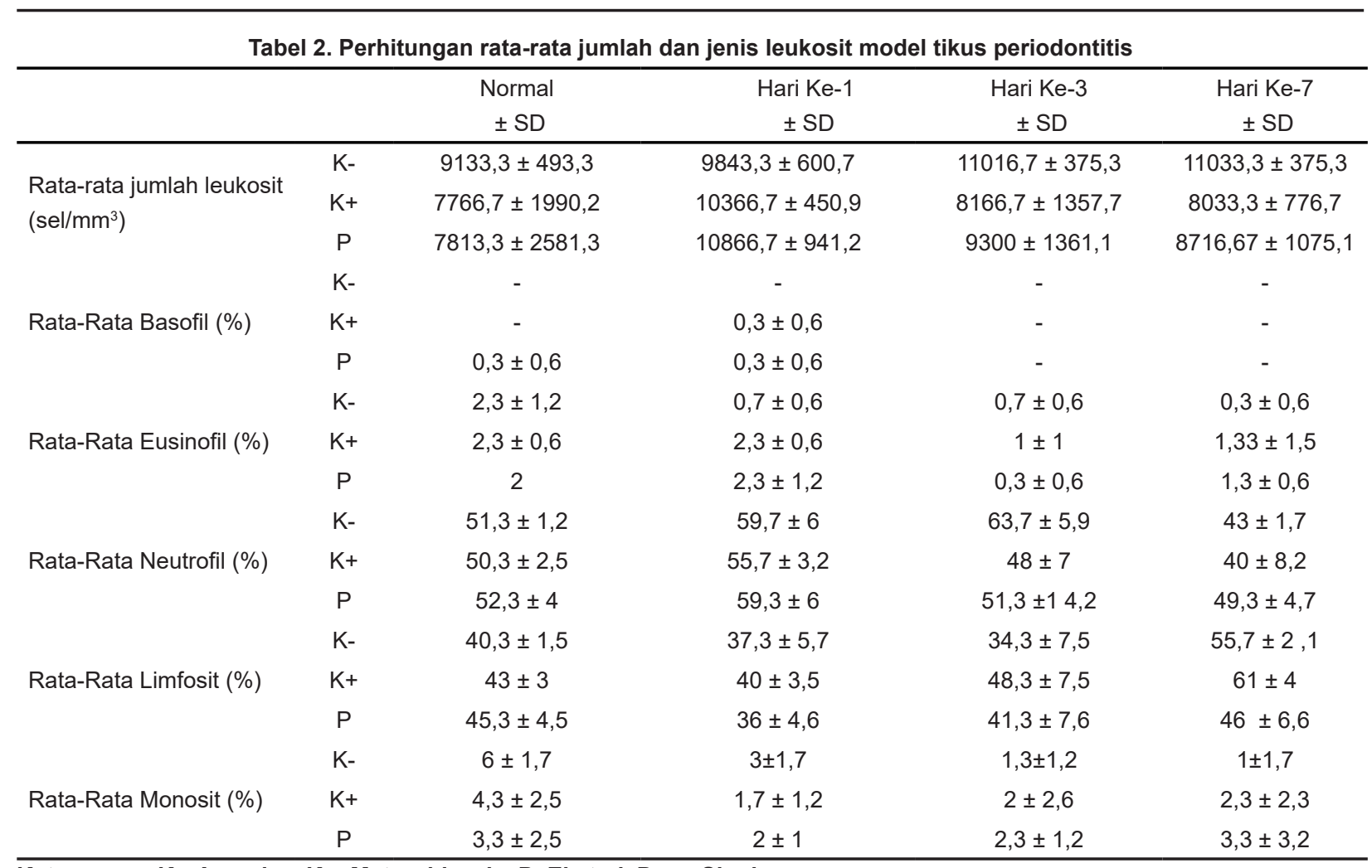

Keterangan: K- :Aquades, K+ :Metronidazole, P :Ekstrak Daun Singkong

Tabel 1 menunjukkan bahwa pada model tikus disfungsi ovarium, rata-rata jumlah leukosit tertinggi terdapat pada kelompok tikus yang diberi aquades selama 7 hari. Rata-rata jumlah leukosit paling rendah model tikus disfungsi ovarium terdapat pada kelompok tikus yang diberi metronidazole selama 3 hari. Jenis leukosit yang tertinggi hingga terendah adalah neutrofil, limfosit, monosit, eosinofil, basofil. Neutrofil mengalami penurunan mulai pada hari ke-1, hari ke-3, hingga hari ke-7. Limfosit mengalami peningkatan mulai pada hari ke-1, hari ke-3, hingga hari ke-7.

Tabel 2 menunjukkan bahwa jumlah leukosit model tikus periodontitis memiliki rata-rata hitung jumlah tertinggi pada hari ke-7 kelompok tikus yang diberi aquades. Rata-rata jumlah leukosit darah tepi terendah model tikus periodontitis terdapat pada hari ke-7 kelompok tikus yang diberi metronidazole. Jenis leukosit baik pada kondisi normal, hari ke-28 maupun hari ke-3 jenis leukosit yang tertinggi hingga terendah adalah neutrofil, limfosit, monosit, eosinofil, basofil. Pada hari ke-7 neutrofil mulai mengalami penurunan namun jumlah limfosit mengalami peningkatan.

Penghitungan jenis dilakukan menggunakan mikroskop dengan perbesaran 1000x. Sel leukosit memiliki morfologi yang berbeda berdasarkan jenisnya. Hasil pengamatan morfologi dari sel leukosit pada penelitian ini dapat dilihat pada gambar 1.
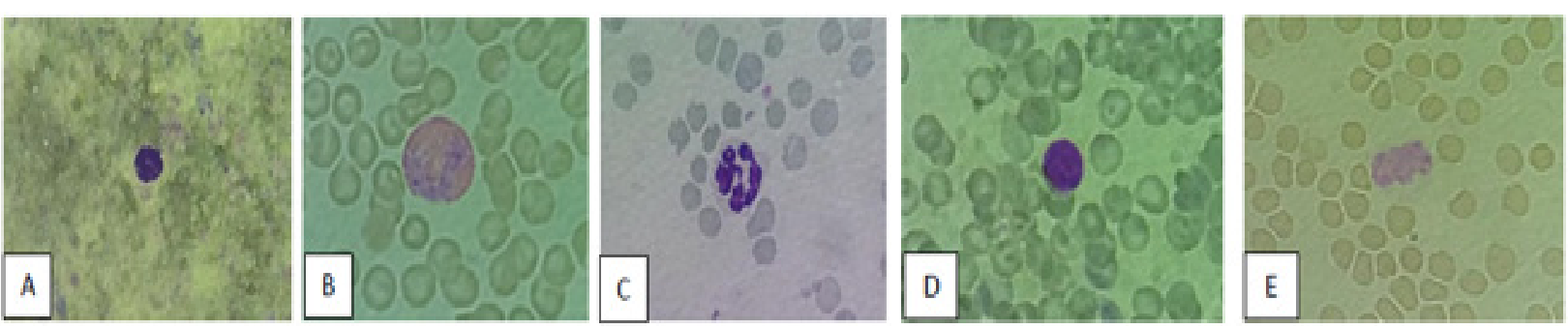

Gambar 1 Jenis sel leukosit dan morfologinya (perbesaran 1000x). A. Basofil B. Eusinofil C. Neutrofil D. Limfosit E. Monosit

Hasil perhitungan jumlah dan jenis leukosit yang telah diperoleh kemudian dilakukan analisis. Hasil dari analisis data hitung jumlah dan jenis leukosit darah tepi model tikus disfungsi ovarium (Tabel 3). Hasil dari analisis data hitung jumlah dan jenis leukosit model tikus periodontitis (Tabel 7). 


\begin{tabular}{|c|c|c|c|c|c|c|}
\hline \multirow{2}{*}{ Jenis uji } & \multicolumn{6}{|c|}{ Signifikansi ( $p$ value) } \\
\hline & Jumlah leukosit & Basofil & Eusinofil & Neutrofil & Limfosit & Monosit \\
\hline Normalitas $(p$ value $>0,05)$ & 0,260 & 0,000 & 0,002 & 0,094 & 0,830 & 0,395 \\
\hline Homogenitas ( $p$ value $>0,05)$ & 0,469 & & & 0,629 & 0,845 & 0,187 \\
\hline \multicolumn{7}{|c|}{ Two way repeated measure $(p$ value $<0,05)$} \\
\hline Perlakuan & 0,399 & & & $0,031^{*}$ & $0,028^{*}$ & 0,406 \\
\hline Hari & $0,030^{*}$ & & & $0,003^{*}$ & $0,000^{*}$ & 0,114 \\
\hline \multicolumn{7}{|l|}{ Friedmann test $(p$ value $<0,05)$} \\
\hline Perlakuan & & 0,368 & 0,584 & & & \\
\hline Hari & & 0,112 & 0,060 & & & \\
\hline
\end{tabular}

Tabel 3 menunjukkan bahwa terdapat perbedaan bermakna jumlah leukosit darah tepi antar hari. Perbedaan bermakna juga didapatkan pada neutrofil dan limfosit antar perlakuan dan antar hari. Untuk mengetahui kelompok mana yang memiliki beda bermakna, maka dilakukan pengujian secara lanjut menggunakan uji Least Different Significant (LSD). Hasil uji LSD antar perlakuan ditunjukkan pada gambar 2 sedangkan hasil uji LSD antar hari ditunjukkan oleh Tabel 4, Tabel 5 dan Tabel 6.

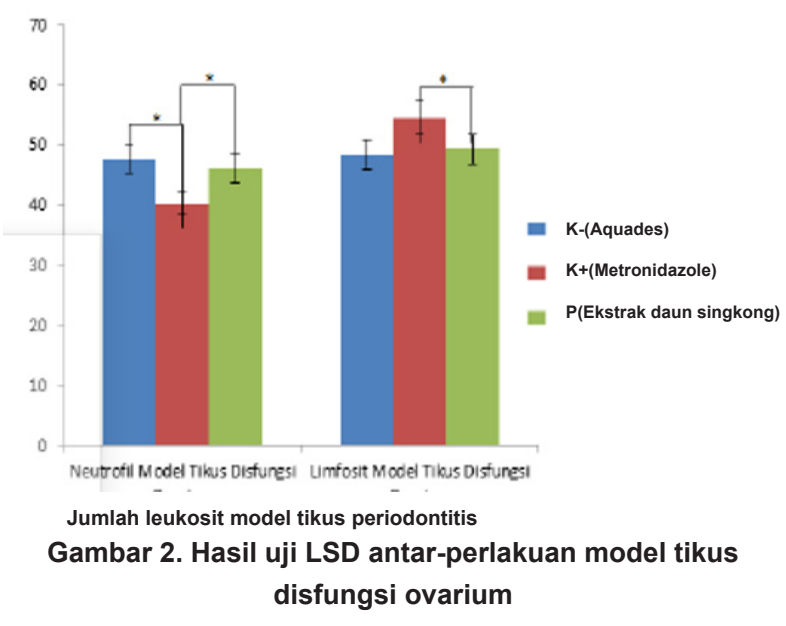

Gambar 2 menunjukkan bahwa terdapat perbedaan bermakna jumlah neutrofil pada kelompok model tikus disfungsi ovarium yang diberi aquades dengan metronidazole dan kelompok metronidazole dengan ekstrak daun Singkong. Jumlah limfosit model tikus disfungsi ovarium yang diberi metronidazole dan ekstrak daun Singkong juga memiliki perbedaan bermakna.

Berdasarkan tabel 4 terdapat perbedaan bermakna jumlah leukosit (PMN) model tikus disfungsi ovarium antar hari. Pada waktu normal memiliki perbedaan jumlah leukosit dengan hari ke7. Pada hari ke-1 dan hari ke-3 memiliki perbedaan
Tabel 4. Hasil uji LSD jumlah leukosit model tikus disfungsi ovarium antar-hari

\begin{tabular}{lcccc}
\hline $\begin{array}{l}\text { Jumlah leukosit } \\
\text { model tikus disfungsi } \\
\text { ovarium antar hari }\end{array}$ & Normal & $\begin{array}{c}\text { Hari } \\
\text { ke-1 }\end{array}$ & $\begin{array}{c}\text { Hari } \\
\text { ke-3 }\end{array}$ & $\begin{array}{c}\text { Hari } \\
\text { ke-7 }\end{array}$ \\
\hline Normal & - & 0,066 & 0,195 & $0,045^{*}$ \\
Hari ke-1 & & - & 0,553 & $0,038^{*}$ \\
Hari ke-3 & & & - & $0,002^{*}$ \\
Hari ke-7 & & & & - \\
\hline
\end{tabular}

Tabel 5. Hasil uji LSD jumlah neutrofil model tikus disfungsi ovarium antar-hari

\begin{tabular}{lcccc}
\hline $\begin{array}{l}\text { Jumlah neutrofil } \\
\text { model tikus } \\
\text { disfungsi ovarium } \\
\text { antar hari }\end{array}$ & Normal & $\begin{array}{l}\text { Hari } \\
\text { ke-1 }\end{array}$ & $\begin{array}{c}\text { Hari } \\
\text { ke-3 }\end{array}$ & $\begin{array}{c}\text { Hari } \\
\text { ke-7 }\end{array}$ \\
\hline Normal & - & $0,007^{*}$ & $0,000^{*}$ & $0,000^{*}$ \\
Hari ke-1 & & - & $0,015^{*}$ & 0,118 \\
Hari ke-3 & & & - & $0,005^{*}$ \\
Hari ke-7 & & & & - \\
\hline
\end{tabular}

bermakna dengan hari ke-7 (terdapat notasi bintang). Tidak ada beda bermakna pada hari ke-1 dengan hari ke-3 (tidak terdapat notasi bintang).

Berdasarkan tabel 5 terdapat perbedaan bermakna jumlah neutrofil model tikus disfungsi ovarium antar hari. Pada waktu normal memiliki perbedaan jumlah leukosit dengan hari ke-1, hari ke-3 dan hari ke-7 $\left({ }^{*}\right)$. Pada hari ke-1 memiliki perbedaan bermakna dengan hari ke-3 $\left({ }^{*}\right)$. Tidak ada beda bermakna pada harike-1 dengan harike-7.

Berdasarkan tabel 6 terdapat perbedaan bermakna jumlah limfosit (PMN) model tikus disfungsi ovarium antar hari. Pada waktu normal memiliki perbedaan jumlah leukosit dengan hari ke-1 hari ke-3 dan hari ke-7 $\left(^{*}\right)$. Pada hari ke-1 memiliki perbedaan bermakna dengan hari ke-3 $\left(^{*}\right)$. Tidak ada beda bermakna pada hari ke-1 dengan hari ke-7. 
Tabel 6. Hasil uji LSD jumlah limfosit model tikus disfungsi ovarium antar-hari

\begin{tabular}{|c|c|c|c|c|}
\hline Jumlah limfosit model tikus disfungsi ovarium antar hari & Normal & Hari ke-1 & Hari ke-3 & Hari ke-7 \\
\hline Normal & - & $0,000^{*}$ & $0,001^{*}$ & $0,006^{*}$ \\
\hline Hari ke-1 & & - & $0,010^{*}$ & 0,134 \\
\hline Hari ke-3 & & & - & $0,022^{*}$ \\
\hline Hari ke-7 & & & & - \\
\hline
\end{tabular}

Tabel 7. Hasil uji ANOVA model Periodontitis

\begin{tabular}{|c|c|c|c|c|c|c|}
\hline \multirow{2}{*}{ Jenis uji } & \multicolumn{6}{|c|}{ Signifikansi ( $p$ value) } \\
\hline & Jumlah leukosit & Basofil & Eusinofil & Neutrofil & Limfosit & Monosit \\
\hline Normalitas ( $p$ value $>0,05$ ) & 0,079 & 0,000 & 0,000 & 0,333 & 0,047 & 0,005 \\
\hline Homogenitas $(p$ value $>0,05)$ & 0,532 & & & 0,759 & & \\
\hline \multicolumn{7}{|c|}{ Two way repeated measure ( $p$ value $<0,05$ ) } \\
\hline Perlakuan & $0,018^{*}$ & & & 0,296 & & \\
\hline Hari & 0,199 & & & 0,065 & & \\
\hline \multicolumn{7}{|l|}{ Friedmann test $(p$ value $<0,05)$} \\
\hline Perlakuan & & 0,223 & 0,395 & & 0,174 & 0,779 \\
\hline Hari & & 0,194 & 0,153 & & 0,072 & 0,167 \\
\hline
\end{tabular}

Berdasarkan tabel 7 menunjukkan bahwa terdapat perbedaan bermakna jumlah leukosit antar perlakuan $\left(^{*}\right)$. Untuk mengetahui kelompok mana yang memiliki beda bermakna, maka dilakukan pengujian secara lanjut menggunakan uji Least Difference Significant (LSD). Hasil Uji LSD ditunjukkan oleh gambar 3.

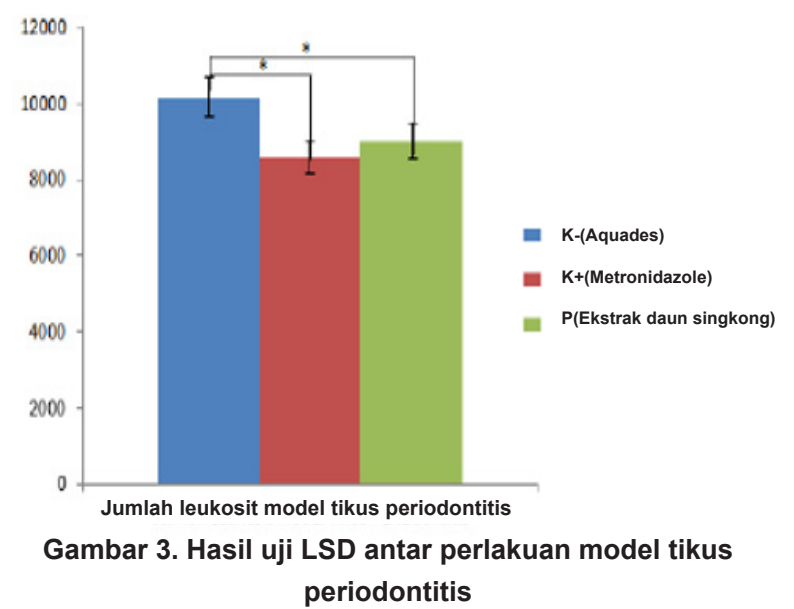

Gambar 3 menunjukkan bahwa terdapat perbedaan bermakna jumlah leukosit antara model tikus periodontitis yang diberi aquades dengan metronidazole. Kelompok model tikus periodontitis yang diberi aquades juga memiliki perbedaan bermakna dengan kelompok yang diberi ekstrak daun Singkong. Tidak ada perbedaan bermakna model tikus periodontitis yang diberi metronidazole dengan ekstrak daun Singkong.

\section{PEMBAHASAN}

Kondisi disfungsi ovarium akan mengakibatkan menurunnya sintesis estrogen. Berkurangnya sintesis estrogen ini menyebabkan terjadinya peningkatan sitokin pro-inflamasi seperti IL-1, IL-6 dan TNF- $\alpha .{ }^{11}$ Pada kondisi periodontitis, sitokin pro-inflamasi dihasilkan oleh sel makrofag akibat adanya infeksi yang bersifat lokal. ${ }^{12}$ Peningkatan sitokin pro-inflamasi dapat mempengaruhi kadar leukosit dalam darah. ${ }^{13}$

Hasil penelitian jumlah leukosit pada model tikusdisfungsiovariummenunjukkanbahwaterdapat perbedaan bermakna antara hari. Hal ini dapat disebabkan karena disfungsi ovarium prematur akibat ovariektomi menekan produksi leukosit dan menyebabkan penurunan sistem imun. ${ }^{1,14}$ Penelitian yang dilakukan Kovanen, et al. ${ }^{15}$ juga menyatakan bahwa jumlah total leukosit pada wanita yang mengalami menopause mengalami penurunan dan mengalami perubahan komposisi leukosit.

Hasil hitung jumlah leukosit model tikus periodontitis menunjukkan perbedaan signifikan antara perlakuan. Terdapat perbedaan antara kelompok yang diberi aquades dengan metronidazole dan kelompok yang diberi aquades dengan ekstrak daun singkong. Metronidazole digunakan sebagai kontrol positif. Metronidazole adalah zat yang bersifat bakterisidal terhadap bakteri anaerob, sehingga efektif untuk penyakit 
periodontal yang disebabkan oleh Porphyromonas Gingivalis, Prevotella Intermedia, Brotella Forsythus, Falciparum Nucleatum. Metronidazole bekerja dengan cara menghambat sintesis DNA bakteri. ${ }^{16}$

Pemberian ekstrak daun singkong diharapkan mampu berperan sebagai anti inflamasi akibat kandungan flavonoid, saponin dan tanin yang ada di dalamnya. Mekanisme antiinflamasi yang dihasilkan oleh flavonoid dapat terjadi melalui penghambatan aktivitas enzim COX dan lipooksigenase. Jika jalur siklooksigenase dan lipooksigenase terhambat maka pembentukan prostaglandin dan leukotrien juga akan berkurang. Berkurangnya pembentukan tersebut mengakibatkan kemotaktik leukosit ikut berkurang dan dapat menekan proses inflamasi. ${ }^{17,18}$

Mekanisme lain flavonoid sebagai antiinflamasi adalah dengan menghambat sekresi mediator proinflamasi. ${ }^{19}$ Salah satu mediator proinflamasi yang dihambat oleh flavonoid adalah TNF- $\alpha$. Menurut penelitian yang dilakukan oleh Meilawaty $\mathrm{dkk}^{8}$ flavonoid dapat menurunkan ekspresi TNF- $\alpha$ pada model tikus periodontitis. Flavonoid juga diketahui dapat menghambat adhesi leukosit pada cedera iskemia-reperfusi pada hamster. Penurunan jumlah leukosit mungkin terkait dengan penurunan komplemen serum total, selain itu flavonoid telah terbukti menghambat degranulasi neutrofil tanpa mempengaruhi produksi superoksida. ${ }^{20}$

Mekanisme saponin sebagai anti-inflamasi adalah dengan cara menghambat kenaikan permeabilitas vaskuler. ${ }^{21}$ Saponin juga diketahui dapat menghambat pelepasan histamin, serotonin, kinin, prostaglandin dan bradikinin. ${ }^{22}$

Tanin memiliki fungsi sebagai antioksidan sekaligus anti-inflamasi. Tanin dapat mentransfer sebuah elektron ke senyawa radikal bebas. Tannin dapat menghambat produksi oksidan oleh neutrofil, monosit dan makrofag. Penghambatan produksi oksidan akan menghambat peroksidasi lipid yang menyebabkan respon inflamasi. ${ }^{23}$

Basofil dan eosinofil pada model tikus disfungsi ovarium maupun model tikus periodontitis merupakan persentase yang terkecil dari jenis leukosit. Tidak terdapat perbedaan signifikan baik antar-perlakuan maupun antar-hari. Persentase basofil dan eosinofil akan meningkat apabila terjadi reaksi alergi dan infeksi parasit. ${ }^{24}$
Neutrofil pada kondisi disfungsi ovarium mengalami penurunan persentase. Wanita yang mengalami menopause menunjukkan penurunan persentase neutrofil yang diduga akibat level estradiol yang menurun. ${ }^{25}$ Dalam sistem imun bawaan, estrogen mengatur jumlah produksi, kemotaksis, dan infiltrasi neutrofil dan makrofag dimana kedua jenis sel leukosit juga berperan dalam proses inflamasi. ${ }^{26}$ Level estradiol menurun maka jumlah neutrofil juga akan menurun. Pemberian metronidazole juga dapat mempengaruhi persentase neutrofil. Metronidazol diketahui menyebabkan efek samping hematologi, termasuk neutropenia ringan yang reversibel; dalam keadaan yang jarang, trombositopenia juga dikaitkan dengan pengobatan metronidazol. ${ }^{27}$

Limfosit pada model tikus disfungsi ovarium mengalami peningkatan persentase. Estradiol mempunyai peran mengurangi produksi limfosit di sumsum tulang. Hasil penelitian tersebut menunjukkan bahwa pada wanita masa menopause mengalami peningkatan persentase limfosit yang diakibatkan oleh penurunan level estradiol. ${ }^{25}$

Monosit pada model tikus disfungsi ovarium dan periodontitis tidak menunjukkan perbedaan yang signifikan antar hari dan antar-perlakuan. Monosit berfungsi sebagai pengganti neutrofil dan akan berdiapedesis dari endotel menuju jaringan untuk melakukan fagositosis. ${ }^{28}$

\section{SIMPULAN}

Terjadi penurunan profil leukosit darah tepi model tikus disfungsi ovarium dan periodontitis yang diberi ekstrak daun Singkong (Manihot esculenta Crantz).

\section{DAFTAR PUSTAKA}

1. Wratsangka R. Soy isoflavone supplementation tends to improve specific immune responsses in postmenopausal women. Univ Med. 2011;30(3):162-72. DOI: $10.18051 /$ UnivMed.2011.v30.162-172

2. Soejono S, Susanto HS, Udiyono A, Adi MS. Gambaran penyakit periodontal pada wanita menopause di Puskesmas Srondol, Kota Semarang. J Kes Masyarakat (e-Journal). 2016;4(4): 465-469.

3. Lee YH, Kim SM, dan Ahn E. Relationship 
between early menopause and periodontal disease in korean postmenopausal women. J Dent Hyg Sci. 2018;18(5): 312-318. DOI: 10.17135/jdhs.2018.18.5.312

4. Wati SM, Istiati, Soesilawati P. Characterization of lactoferrin in gingival crevicular fluid of chronic periodontitis patient. Dent. J. (Maj. Ked. Gigi). 2014;47(3): 141-145. DOI: 10.20473/i. djmkg.v47.i3.p141-145

5. Kapoor, A., Malhotra,R., Grover,V., Grover, D. Systemic Antibiotic Therapy in Periodontics. Dent Res J. 2012;9(5):505-15. DOI: 10.4103/1735-3327.104866

6. Rikomah SE, Elmitra, Yunita DG. Efek ekstrak etanol daun singkong (manihot utilissima pohl) sebagai obat alternatif anti rematik terhadap rasa sakit pada mencit. J IIm Manuntung. 2017;3(2):133-8. DOI: 10.51352/jim.v3i2.119

7. Nisa, VM, Meilawaty Z, Astuti P. Efek Pemberian Ekstrak Daun Singkong (manihot esculenta) terhadap Proses Penyembuhan Luka Gingival Tikus (Rattus norvegicus). Artikel IImiah Hasil Penelitian Mahasiswa.Skripsi.Jember:Fakultas Kedokteran Gigi Universitas Jember. 2013.

8. Meilawaty Z, Kusumawardani B. Effect of Cassave leaf flavonoid extract on TNF- $\alpha$; expressions in rat models suffering from periodontitis. Dent JMajKed Gi. 2016;49(3):137. DOI:10.20473/j.djmkg.v49.i3.p137-142.

9. Suci-Dharmayanti AW, Ermawati T, Febrianto B. Ovarian Failure Affected Leukocytes Profile In Peripheral Blood And Gingival Fluid (In Vivo Study). In: The $2^{\text {nd }}$ International Conference in Health Sciences (ICHS). 2017. p. 1-8.

10. Kusumawardani B. Dampak Infeksi Porphyromonas gingivalis pada Jaringan Periodontal Maternal terhadap Pertumbuhan Janin : Analisis Pengaruh Ekspresi TLR-2, TLR4, TNF, IL-10 dan capcase-3 pada Plasenta Tikus terhadap Penurunan Berat Plasenta, Berat Janin dan Panjang Janin. Disertasi. Yogyakarta: Universitas Gadjah Mada. 2012.

11. Abraham A, Pullishery F. The effect of menopause on the periodonsium-A Review. J Interdiscipl Med Dent Sci. 2015;3(2):1-4. DOI: 10.4172/2376-032X.1000170.

12. Rusyanti Y. 2014. Analisis Kadar Interleukin-8 pada Periodontitis Agresif. IJAS. 4(3):154-61. DOI: 10.24198/.v4i3.16816.g8113

13. Santoso S, Rachmawati B, dan Retnoningrum
D. Perbedaan jumlah leukosit, neutrofil dan limfosit absolut pada penderita DM tipe 2 terkontrol dan tidak terkontrol. J Ked Diponegoro. 2018;7(2):854-62.

14. Baeza, I, Castro NMD, Arranz L, FdezTresguerres J, Fuente MD. Ovariectomy causes immunosenescence and oxi-inflamm-ageing in peritoneal leukocytes of aged female mice similar to that in aged males. Biogerontology. 2011;12(3):227-38. DOI: 10.1007/s10522-0109317-0

15. Kovanen V, Aukee P, Kokko K, Finni T, Tarkka IM, Tammelin $\mathrm{T}$, et al. Design and protocol of estrogenic regulation of muscle apoptosis (ERMA) study with 47 to 55-yearold women's cohort: novel results show menopause-related differences in blood count. Menopause. 2018;25(9):1-13 DOI: 10.1097/ GME.0000000000001117

16. Setiawan A, Lastianny SP, Herawati D. Efektivitas aplikasi madu murni terhadap penyembuhan jaringan periodontal pada perawatan periodontitis penderita hipertensi. J Ked Gi. 2013;4(4):228-35.

17. Pramitaningastuti AS, Anggraeny EN. Uji efektivitas antiinflamasi ekstrak etanol daun srikaya (Annona squamosa. L) terhadap udema kaki tikus putih jantan galur wista. J IIm Farmasi. 2017;13(1):8-13.

18. Nasution AM, Kamaluddin MT, dan Theodorus. 2017. Efek Antiinflamasi Ekstrak Air Daun MaliMali (Leea indica) terhadap Jumlah Leukosit pada Tikus Putih Jantan Galur Wistar. Majalah Kedokteran Sriwijaya, 2017;49(3):110-7. DOI: https://doi.org/10.36706/mks.v49i3.8507

19. Handajani F, Prabowo S. Peran ekstrak sargassum duplicatum terhadap penurunan edema sendi pergelangan kaki tikus dengan artritis ajuvan yang terpajan stresor dingin. eJKI. 2019;7(2):137-42.

20. Panche AN, Diwan AD, Chandra SR. Flavonoids: An overview. J Nutri Scie. 2016;5:1-15. DOI: 10.1017/jns.2016.41

21. Fitriyani A, Winarti L, Muslichah S, Nuri. Uji antiinflamasi ekstrak etanol daun sirih merah (Piper crocatum Ruiz \& Pav) pada tikus putih. Maj Obat Trad. 2011;16(1):34-42.

22. Hassan HS, Sule MI. Musa KY. et al. 2012. Anti-Inflammatory Activity of Crude Saponin Extracts from Five Nigerian Medicinal Plants. 
AJTCAM. 2012;9(2):250-5. DOI: $10.4314 /$ ajtcam.v9i2.10

23. Elvina L. Aktivitas Antiinflamasi Ekstrak Etanol Kulit Mangga (Magnifera Indica L.) Indramayu pada Mencit Jantan Galur Swiss Terinduksi Karagenin 1\%. Skripsi. Yogyakarta: Fakultas Farmasi Universitas Sanata Dharma. 2018.

24. Kiswari R. Hematologi dan transfusi. Jakarta: Erlangga. 2014.

25. Chen Y, Zhang Y, Zhao G, Chen C, Yang P, Ye $S$, et al. Difference in leukocyte composition between women before and after menopausal age, distinc sexual dimorphism. PLoS ONE. 2016;11(9):1-10. DOI: 10.1371/journal. pone. 0162953

26. Khan D, Ahmed SA. The immune System is a natural Target for estrogen Action: Opposing effects of estrogen in Two Prototypical Autoimmune Diseases. Frontiers in Immunology. 2016;6:635. DOI: 10.3389/ fimmu.2015.00635.

27. Sam AM, Saunder LM, Taplitz R, Koura D. A case of Aplastic Anemia Associated With Long-Term Metronidazole Use. J Pharm Prac 2019;20(10):1-3. DOI: 10.1177/0897190019825584

28. Prasetya RC, Purwanti N, Haniastuti T. 2014. Infiltrasi Neutrofil pada Tikus dengan Periodontitis setelah Pemberian Ekstrak Etanolik Kulit Manggis. Maj Ked Gi. 2014;21(1):33-8. DOI: $10.22146 /$ majkedgiind.8520 